\title{
Sejarah Dakwah Pada Masa Bani Umayyah
}

\section{Hatmansyah}

\section{UIN Antasari Banjarmasin}

\begin{abstract}
The Umayyah dynasty became a major force in the development of propaganda spread throughout the world as well as being one of the first centers of political, cultural and scientific studies in the world since the Middle Ages. At the height of its greatness, its success in expanding Islamic power was far greater than that of the Roman empire. The history of Islamic preaching in the Umayyah Dynasty can be divided into two periods in the dynasty era in Damascus and in Cordoba. Islamic da'wah at this time was carried out in three stages, first the expansion of the da'wah area, the second was the development of science and the third was economic thought.
\end{abstract}

Keywords: History; Da'wah; Umayyah

\section{Pendahuluan}

Dinasti Umayyah (661-750 M) merupakan dinasti besar pertama dalam pemerintahan kekaisaran khalifah Muslim, Dinasti Umayyah dipimpin oleh Muawiyah bin Abi Sofyan, adalah keluarga besar pedagang suku Quraish yang berpusat di Mekkah. Mereka awalnya menentang Islam karena Bani Umayyah selalu bersaing dengan Bani Hasyim, pada awalnya Bani Umayyah lebih mendominasi dan meguasai pemerintahan dan perdagangan dalam masyarakat Makkah dikarenakan telah yang banyak bergantung kepada pengunjung Ka'bah, dibandingkan dengan Bani Hasyim adalah orang-orang yang sederhana, maka seiring dengan berkembangnya agama islam Bani Umayyah merasa terancam dan menjadi penentang utama dalam 
perjuangan Nabi Muhammad, namun setelah islam kuat dan mampu merebut Makkah saat peristiwa yang dikenal dengan Fathul Makkah, Abu Sufyan beserta sekutunya meyerah dan kemudian memeluk agama islam hingga tahun $627 \mathrm{M}$.

Awal berperannya Bani Umayyah dalam sejarah Islam adalah menjadi administrator terkemuka pada masa pimpinan Nabi Muhammad dan episode pemerintahan berikutnya. Pada masa khalifah ketiga 'Uthmān ibn 'Affān (644-656 M) Mua'awwiyah bin Abi Sofyan menjabat sebagai gubernur Siria kemudian pada masa khalifah Ali r.a (khalifah keempat yang menjadi anak menantu Nabi Muhammad SAW) Mua'awwiyah bin Abi Sofyan melakukan agitasi dan menuntut pengungkapan dalang atas pembunuhan 'Uthmān ibn 'Affān hingga terjadi peristiwa perang saudara pertama dalam sejarah antar sesama umat Islam (fitnah; 656-661 M), peperangan tersebut dimenangkan Mua'awwiyah bin Abi Sofyan atas 'Alī r.a dan kemudian mendeklarasikan dirinya sebagai khalifah Umayyah Pertama dengan menjadikan Suriah sebagai basis kekuatan utama dan Kota Damaskus sebagai ibu kotanya.

Pandangan sebagian sejarawan citra negatif melekat pada Dinasti Umayyah ini karena adanya sengketa politis akan legalitas kekuasaan tidak dilakukan secara demokratis (sebagaimana kekhalifahan sebelumnya), namun berubah menjadi monarchiheridetis (Dinasti turun-temurun) hal ini dapat dilihat ketika dia mewajibkan seluruh rakyatnya untuk menyatakan setia terhadap anaknya, yaitu Yazid bin Muawiyah. Selain persepsi negative bukan berarti menafikan apa yang dihasilkan oleh Dinasti Muawiyyah ini, pada era ini wilayah kekhalifahan tumbuh pesat dan Kekhalifahan Islam menjadi salah satu negara kesatuan terbesar dalam sejarah yang memerintah langsung atas tiga benua (Afrika, Eropa, dan Asia), meskipun tidak 
memerintah semua kawasan Sahara, namun suku-suku Berber nomaden tetap memberi penghormatan kepada khalifah, wilayah yang luas ini mengakui supremasi khalifah secara de facto kekuasaan berada di tangan sultan dan pemimpin lokal.

Demikian Dinasti Umayyah menjadi suatu kekuatan besar dalam perkembangan dakwah menyebar keseluruh dunia serta sebagai salah satu pusat kajian politik, budaya, dan ilmiah pertama di dunia sejak abad pertengahan. Pada puncak kebesarannya adalah keberhasilannya dalam melakukan ekspansi kekuasaan islam jauh lebih besar daripada imperium Roma, keberhasilan ini diikuti pula oleh keberhasilan perjuangan bagi penyebaran syariat islam, baik di bidang keagamaan, politik dan ekonomi. ${ }^{29}$

\section{Pembahasan}

\section{Perkembangan Dakwah}

Dinasti Umayyah yang berada di Damaskus selama pemerintahannya telah terjadi pergantian sebanyak 14 orang Khalifah. Mereka adalah Muawiya I ibn Abu Sufyan (661 -680), Yazid I ibn Muawiyah (680 -683), Muawiya II ibn Yazid (683-684), Marwan I ibn al-Hakam (684-685), Abd al-Malik ibn Marwan (685 -705), al-Walid I ibn Abd al-Malik (705 -715), Sulayman ibn Abd al-Malik (715 -717), Umar ibn Abd al-Aziz (717 -720), Yazid II ibn Abd al-Malik (720 -724), Hisham ibn Abd al-Malik (724 -743), al-Walid II ibn Yazid (743-744), Yazid III ibn al-Walid (744 -744), Ibrahim ibn al-Walid (744-744), Marwan II ibn Muhammad (744 -750). Sedangkan Kebangkitan Kekhalifahan Umayyah di Al-Andalusia (Spanyol) disebut Kekhalifahan Córdoba (yang berlangsung hingga 1031), memiliki beberapa

\footnotetext{
${ }^{29}$ Siti Maryam (ed.) dkk. Sejarah Peradaban Islam: Dari Masa Klasik Hingga Modern. Yogyakarta: LESFI, 2004. Hal. 67
} 
khalifahnya antara lain, Abdur-rahman III, (929-961), Al-Hakam II (961-976), Hisyam II (976-1008), Muhammad II (1008-1009), Sulaiman (1009-1010), Hisyam II (1010-1012), Sulaiman (kembali) (1012-1017), Abdur-rahman IV (1021-1022) Abdur-rahman V (1022-1023), Muhammad III (1023-1024), Hisyam III (1027-1031). 30

Perkembangan dakwah pada dinasti Umayyah dapat dikatakan memiliki banyak kegiatan baik yang sifatnya ke dalam maupun ke luar, ke dalam merupakan tindakan pembinaan dan konsolidasi, sedang ke luar merupakan usaha pelebaran wilayah dakwah. Sayyid Qutub mengatakan kalau bukan karena kekuatan besar yang dimiliki watak agama ini niscaya masa-masa pemerintahan Bani Umayyah dapat dijadikan jaminan bagi lenyapnya Islam dimuka bumi. ${ }^{31}$ Perspektif penerimaan negatif dari sejarawan Islam terhadap dinasti umayyah yang telah menjadikan suatu dinas (mulk, sebuah istilah dengan konotasi tirani) bukan khilafah sejati (khilafah), karena dalam argumentasinya khalifah Umayyah menyebut diri mereka bukan sebagai Khalifaturrasulullah khalifat rasul Allah (penerus utusan Allah), melainkan dinasti umayyah merupakan Khalifatullah (wakil Allah). Ini bukan berarti menafikan bahwa apa yang dihasilkan oleh Dinasti Umayyah yang berlangsung hampir satu abad, telah banyak memberi kontribusi yang sangat besar terhadap perkembangan islam ke seluruh dunia, sebagaimana membuka wilayah dakwah baru, dakwah dibidang kajian dan penulisan ilmiah, memakmurkan masjid dengan kajian keagamaan, pemurnian dan penggakan Bahasa arab, pengumpulan penulisan dan peletakan dasar-dasar metodologis Hadis, bidang hukum islam. ${ }^{32}$ Secara garis besar bahwa

\footnotetext{
${ }^{30} \mathrm{https}: / /$ en.wikipedia.org/wiki/List_of_Caliphs

${ }^{31}$ Sayyid qutub, Keadilan Sosial dalam Islam (Bandung: Pustaka Bandung, 1984), 311-312

${ }^{32}$ Wahyu Ilaihi, S.Ag., MA dan Harjani Hefni, Lc., MA, Pengantar Sejarah Dakwah, Jakarta: Kencana Prenada Media Group 2007
} 
perkembangan dakwah pada masa Dinasti Abbasiyah meliputi Perluasan wilayah Dakwah, Pengembangan dan Pembinaan ilmu, dan Pemikiran dibidang Ekonomi.

\section{Memperluas Wilayah Dakwah}

Guna mempertahankan kelangsungan dakwah Islamiyah dari dua ancaman kekuatan besar dunia pada saat itu, yakni kerajaan Romawi Timur dan kerajaan Persia. Maka daulat Bani Umaiyah memandang perlu mengambil langkah-langkah kebijaksanaan dalam rangka upaya menyelamatkan dan penyebaran dakwah Islamiyah. Atas dasar konsederasi inilah, maka kemudian arena perjuangan dan pengenbangan dakwah Islamiyah dilakukan pada tiga wilayah yang luas. Ketiga wilayah itu ialah wilayah asia kecil, wilayah afrika utara dan wilayah timur.

1) Wilayah Asia Kecil

Daulat Bani Umaiyah mengambil Damaskus sebagai ibukota Negara dan sekaligus sebagai pusat kegiatan dakwah, karena itu wilayah Asia Kecil menjadi sangat penting. Sebab apabila wilayah ini dibiarkan begitu saja sama halnya dengan memberi peluang kerajaan Romawi Timur memperkuat dirinya, dan ini memberi kesempatan kepada mereka untuk memukul jantung dakwah Islamiyah.

Justru itulah, rezim Bani Umaiyah terus berusaha memukul jantung kerajaan Romawi Timur yang berpusat di Bizantium. Meskipun untuk ini harus terlebih dahulu berusaha keras menancapkan kakinya di daerah-daerah sekitar Bizantium itu sendiri dan pulau-pulau Laut Tengah seperti pulau Rhodus Kreta, Sicilia, Arwad dan Cyprus.

Satu sisi meskipun Kota Konstantinopel gagal direbut, namun daerahdaerah luas menuju ke sana dapat dikuasai, sehingga memudahkan 
perluasan wilayah dakwah pada masa-masa selanjutnya, minimal membukakan jalan untuk menuju ekspansi wilayah Islam ke daerahdaerah baru.

\section{2) Wilayah Afrika Utara}

Perluasan wilayah dakwah di wilayah ini merupakan tindak lanjut penyempurnaan dari masa Khulafaur Rasyidin. Sehingga Kota Kairawan berhasil dijadikan pusat kegiatan dakwah dan selanjutnya menjadi tempat pengembangan dan penempatan tenaga untuk persiapan ke Andalusia.

Wilayah Afrika Utara ini menjadi sangat kuat setelah bangsa Barbary yang terkenal setia dan gagah berani itu memeluk Agama Islam. Putra-putra bangsa Barbary inilah yang berjasa besar karena telah berhasil melintasi selat Sempit yang sangat strategis dalam membukakan jalan dakwah dalam melanjutkan misinya ke sebagian wilayah Italia dan melintasi pegunungan Pyrenia menuju Perancis.

Pada wilayah Afrika Utara inilah (khususnya di Andalusia) dakwah Islamiyah dapat bertahan sekitar sembilan abad dengan meninggalkan kebudayaan Islam yang tinggi dan mempunyai pengaruh yang besar di mata dunia hingga saat ini.

\section{3). Wilayah Timur}

Melebarnya dakwah Islamiyah melalui wilayah Timur ini, yaitu ke daerah-daerah Seberang Sungai (negeri-negeri yang terletak antara Sungai Jihun / Amu Darya dan Sungai sihun / Syr Darya) dan daerahdaerah Sind (Indus), maka terbukalah baginya jalan menuju Asia Tenggara dan ke Timur Jauh.

Setelah terbukanya daerah Sind tersebut maka terbuka pulalah kemungkinan yang besar bagi berdirinya kerajaan Islam Akra yang 
termasyhur dengan Taj Mahalnya itu. Demikian pula membukakan jalan bagi berdirinya kerajaan Aceh Darussalam di Asia Tenggara dengan ibukota Banda Aceh. Jadi untuk Indonesia buat pertama kalinya Islam masuk melalui Aceh, karena itulah tidak heran kalau Aceh dijuluki dengan nama "Serambi Mekkah".

4). Memasuki Negeri Cina

Khalifah Hisyam bin Abdul Malik (khalifah ke sepuluh dari Bani Umaiyah) pernah mengirim sebuah delegasi di bawah pimpinan perwira tinggi yang bernama Sulaiman kepada Maharaja Cina yang bernama Hswan Tsung. Perwira tinggi yang diutus tersebut adalah dalam rangka untuk mengikat persahabatan. Dengan demikian sejak saat itu terjadilah hubungan bilateral antara daulat Bani Umaiyah dengan kemaharajaan Cina yang pada saat itu sedang dijatuhkan tahtanya oleh suatu pemberontakan.

Dalam kondisi yang demikian Su Tsung putra maharaja Cina ini kemudian minta bantuan kepada khalifah Abi Ja'far Al Mansyur (khalifah kedua dari Bani Abbasiah), permintaan itu dikabulkan dan dikirimlah satu angkatan perang Islam yang cukup kuat sehingga Su Tsung berhasil merebut tahtanya kembali. Sejak saat itulah angkatan perang Islam tersebut tidak kembali lagi ke tanah airnya, malah mereka mengawini putri-putri Cina dan menetap di negeri-negeri Cina. Mulai saat itulah dakwah Islamiyah telah menjejakkan kakinya di bumi Cina yaitu di awal pemerintahan Daulat Bani Abbasiyah sekitar tahun 136/754 M. hingga pada suatu waktu jumlah Muslim Cina sampai lebih dari 50 juta jiwa mendiami satu wilayah luas (Turkistan Timur) atau Tsing Kiang. Pada abad ke 15 H. sekarang ada informasi bahwa di Cina sekarang sudah memiliki Institut Teologi Islam, begitu pula masjid yang dulunya ditutup kini dibuka. Malah ada berita tidak kurang dari 6000 buah masjid kini sedang diperbaiki / dibangun di 
provinsi Xinjiang. Selain itu di negeri Tirai Bambu ini pernah pula diadakan pameran Busana Muslim.

Perluasan dakwah pada masa Daulat Bani Umaiyah ini disebut dengan periode dakwah tahap profesional yang pertama dan kegiatannya masih menitik beratkan pada perluasan daerah. Dalam hal ini misalnya pendaratan pasukan Islam di bawah pimpinan Thariq bin Ziad ke tanah Spanyol, meluaskan wilayah ke Turki, Bukhara, Samarkand dan terus ke Turkistan Cina serta melakukan pengiriman pasukan armada ke India melalui Ceylon. ${ }^{3}$

Kemenangan-kemenangan yang diperoleh umat islam secara luas menjadikan orang-orang Arab bertempat tinggal di daerah-daerah yang dikalahkan itu bahkan mereka telah menjadi tuan-tuan tanah, prinsip keuangan negara diberlakukan mengikuti apa yang ada pada masa khulafaurrasyidin yaitu penetapan pajak tanah (Kharraj) dan pajak perorangan (Jizyah) untuk setiap individu penghuni daerahdaerah yang telah dikalahkan merupakan income bagi pemerintah Umayyah. Hal ini memperlancar terlaksananya system penggajian bagi bala tentara, sehingga memberikan banyak waktu bagi orang-orang Arab untuk berdakwah ${ }^{34}$

\section{Pengembangan dan Pembinaan Ilmu}

Pengembangan dan pembinaan ilmu pada masa Daulat Bani Umaiyah juga merupakan kelanjutan dari apa yang telah dirintis dan diusahakan oleh Rasulullah SAW. dan Khulafaur Rasyidin. Dakwah Islamiyah ini berada pada jalan yang lempang kearah pengembangan dan perluasan bidang-bidang ilmu dengan bahasa Arab sebagai media

\footnotetext{
${ }^{33}$ Drs. Nazaruddin SH., Publisistik dan Da'wah (Persamaan dan Perbedaannya) 1974, hal. 148-149.

${ }^{34}$ Hassan Ibrahim Hassan. Sejarah dan Kebudayaan Islam, Terj. Jahdan Ibnu Humam (Yogyakarta: Kota Kembang, 1989). Hal. 63. Lih juga Siti Maryam (ed.) dkk. Sejarah Peradaban Islam: Dari Masa Klasik Hingga Modern. Yogyakarta: LESFI, 2004. Hal. 73
} 
utamanya. Ilmu-ilmu pengetahuan yang dikembangkan dan dibina ialah seperti ilmu Qiraat, Tafsir, Hadits, Fiqih, Nahwu, Tarikh dan Geografi35.

Selain itu penerjemahan terus dilakukan dalam berbagai disiplin ilmu yang terdiri dari berbagai bahasa ke dalam bahasa Arab. Diantara buku-buku yang diterjemahkan antara lain mengenai Kimia, Fisika, Astronomi, Falak, Kedokteran dan lain-lain.

Upaya melakukan penerjemahan ini diawali oleh Khalid bin Yazid. Bahasa resmi Negara pada saat itu ditetapkan bahasa Arab, sedangkan bahasa Romawi dan Persia ditinggalkan. Itulah sebabnya Mesir, Syam dan negeri-negeri di Afrika Utara telah menjadi sebagai negeri Arab.

Sebagai langkah yang positif dalam usaha pengembangan ilmu, daulat Bani Umaiyah mendirikan sebuah kota kecil sebagai pusat kegiatan ilmu pengetahuan dan kebudayaan, pusat tersebut dinamakan Marbad, kota satelit dari Damaskus. Dalam Kota Marbad itulah berkumpul para pujangga, filosof, ulama, penyair dan sebagainya, sehingga "Ukhad-nya Islam".

Lebih lanjut mengenai pengembangan dan pembinaan ilmu pengetahuan ini pada bagian kedua dari periode Bani Umaiyah ini dimulailah kegiatan kesenian dan arsitektur. Dari sini mulailah dakwah melalui sekolah bersistem lokal / kelas, penyebaran para Ulama sebagai da'i ke berbagai pelosok negeri dan juga ditugaskan melakukan penyeleksian hadits-hadits serta membersihkan tafsirtafsir yang menyeleweng. ${ }^{36}$

Pada zaman Umaiyah para Ulama dan guru Agama turut bersama-sama dengan tentara Islam. Dengan sistem pendidikan, para

\footnotetext{
${ }^{35}$ Samsul Munir Amin, Sejarah Peradaban Islam, Jakarta: Amzah, 2009, hlm. 133.

${ }^{36}$ Nazaruddin. Publisistik dan Da'wah (Persamaan dan Perbedaannya), Jakarta: Erlangga, 1974, hal. 148-149.
} 
guru Agama inilah turut "menambahkan panah dakwah" ke dalam jantung hati umat. Inilah rahasianya mengapa Islam tersebar ke seluruh penjuru dunia dan dianut oleh pemeluk-pemeluknya dengan hati yang lapang dan mesra, bukan dengan paksaan dan kekerasan. Kemudian pada Zaman Bani Umaiyah ini pula dilanjutkan pendidikan yang dirintis di masa Khulafaur Rasyidin yaitu seperti di Damsyik, Iraq, Persia dan Mesir, begitu pula yang ada di pendidikan Mekkah yang ada di Masjidil Haram. ${ }^{37}$

Meskipun ilmu pengetahuan berkembang dengan baik dan perluasan daerah makin maju, akan tetapi secara politis periode Bani Umaiyah ini mengalami kemunduran. Hal ini disebabkan khalifah pertamanya Muawiyah bin Abi Sufyan melalui sistem pemerintahan dinasti atau kerajaan yang berpusat di Damaskus. ${ }^{38}$

Hal tersebut cukup besar dampaknya bagi jatuh bangunnya rezim penerus Khulafaur Rasyidin ini. Malahan pada akhirnya menimbulkan keretakan dalam pemerintahan. Sebagai puncak dari perpecahan keretakan itu ialah dengan lahirnya berbagai partai yang saling bermusuhan. Partai-partai itu adalah Khawarij, Syiah, Zubair, Murjiah dan Mu'tazilah. ${ }^{39}$

\section{Pemikiran Dibidang Ekonomi}

Pemikiran serius terhadap penerbitan dan pengaturan uang dalam masyarakat islam muncul di masa Abdul Malik bin Marwan, beliau mengubah mata uang Bizantium dan Persia dibeberapa daerah yang dikuasai islam, hal ini didasarkan pemikiran bahwa mata uang selain memiliki nilai ekonomi juga sebagai pernyataan kedaulatan

\footnotetext{
${ }^{37}$ Hamzah Ya'qub, Publisistik Islam Teknik Da'wah, Bandung: Diponegoro, 1981 hal. 94.

${ }^{38}$ Nazaruddin., op cit, hal. 149

${ }^{39}$ A. Hasjmy, Sejarah Kebudayaan Islam, Jakarta: Bulan Bintang, 1995, hal. 343-344.
} 
dinasti Islam. ${ }^{40}$ Selain itu khalifah Abdul Malik dalam hal pajak dan zakat memberikan kebijakan dengan memberlakukan kewajiban bagi umat islam untuk membayar zakat dan bebas dari pajak lainnya. Hal inilah yang mendorong orang non-Muslim memeluk agama islam, namun hal ini menimbulkan masalah bagi perekonomian negara, karena disatu sisi perpindahan agama mengakibatkan berkurangnya sumber pendapatan negara dari sektor pajak.

Masa Khalifah Umar bin Abdul Aziz diterapkannya kembali ajaran islam secara utuh dan menyeluruh, mengumumkan dan menyerahkan seluruh harta kekayaan diri dan keluarganya yang tidak wajar kepada kaum muslimin melalui baitul Maal, sebelumnya pada jaman khalifah Muawiyah bin abu sufyan memberlakukan baitul maal sebagai harta kekayaan pribadi yang boleh dipergunakan untuk apa saja oleh sang penguasa Bani umayyah. Khalifah Umar berupaya membersihkan baitul maal dari pemasukan harta yang tidak halal dan berusaha mendistribusikannya kepada yang berhak menerimanya. Khalifah Umar bin Abdul Aziz melindungi dan meningkatkan kemakmuran taraf hidup masyarakat secara keseluruhan. Ia mengurangi beban pajak dari kaum nasrani dari 2000 keping menjadi 200 keping, menghapus pajak terhadap kaum Muslim, membuat takaran dan timbangan, membasmi cukai dan kerja paksa dan lainlain. Berbagai kebijakan berhasil meningkatkan taraf hidup masyarakat secara keseluruhan hingga tidak ada lagi yang mau menerima zakat.

Namun kondisi baitul Maal yang telah dikembalikan oleh Umar bin Abdul Aziz kepada posisi yang sebenarnya tidak dapat bertahan lama. Keserakahan penguasa telah meruntuhkan sendi-sendi Baitul

\footnotetext{
40 Nur Chamid. Jejak langkah Sejarah Pemikiran Ekonomi Islam. Yogyakarta: Pustaka Pelajar. Hal.109
} 
Maal dan keadaan demikian berkepanjangan sampai masa kekhalifahan Bani Abbasyiah.

\section{Diskusi}

Perluasan wilayah di masa dinasti Bani Umaiyah dapat dilakukan dengan baik, sehingga wilayah yang diperoleh dapat difungsikan sebagai kubu pertahanan dalam rangka menghadapi berbagai kemungkinan yang akan muncul mengganggu kelangsungan dakwah Islam. Apalagi pada waktu itu ada dua kekuatan dunia berupa dua kerajaan adikuasa, yakni kerajaan Romawi Timur dan kerajaan Persia.

Wilayah-wilayah baru dapat diamankan dan malah dapat dimanfaatkan sebagai perintis jalan untuk mengembangkan sayap dakwah ke kawasan mancanegara lainnya. Memang perluasan wilayah pada masa ini dapat dikatakan professional dan strategis, sehingga aktifitas dakwah lebih memprioritaskan pelebaran daerah.

Demikian pula halnya dengan pembinaan dan pengembangan ilmu pengetahuan dapat dilaksanakan dengan baik, sehingga dapat/biasa dikatakan sebagai revolusi ilmu pengetahuan, baik pengetahuan Agama maupun umum. Di sinilah terjadi kontak pemikiran barat ke dalam pemikiran Islam, terutama melalui penerjemahan filsafat Yunani.

Meskipun juga harus diakui upaya Bani Umaiyah dalam membina dan mengembangkan ilmu sebagai realisasi dakwah itu adalah kelanjutan dari usaha-usaha yang telah diletakkan dasardasarnya oleh Rasulullah SAW. Dan Khulafaur Rasyidin. Namun langkah yang ditempuh oleh dinasti bani Umaiyah merupakan enovasi dan pembaruan sebagai seuatu prestasi ilmiah. 
Ilmu pengetahuan yang sampai kepada kita hari ini adalah buah daripada apa yang dihasilkan pada masa bani Umaiyah dulu. Paling tidak ada hubungan yang tidak terputus kepadanya. Sebagai contoh, Muballigh yang handal bersama-sama tentara Islam dalam suatu peperangan, sehingga bila peperangan telah usai mereka pun melepaskan baju militer dan tidak lagi memanggul senjata, tetapi tampil sebagai da'i, memanggil umat manusia ke jalan yang lurus, yakni Agama Islam. Sistem seperti ini dilakukan dengan persi yang berbeda tetapi tujuannya sama, yaitu mengirimkan da'I pada masyarakat terasing atau yang membutuhkan siraman rohani.

Semua keberhasilan pada masa rezim setelah Khulafaur Rasyidin itu tentu saja didukung oleh factor mitode dan media pendekatan yang diterapkan, baik dalam melakukan perluasan daerah maupun dalam membina dan mengembangkan ilmu pengetahuan. Minimal dalam semuanya itu mereka mengaplikasikan pendekatan yang tepat dengan situasi serta kondisi pada waktu itu.

Jadi tegasnya dalam kerangka dakwah Islamiyah di masa Bani Umaiyah berkuasa, mereka menggunakan metode dan media yang tepat guna, walaupun bersifat kondisional dan situasional. Artinya seperangkat mitode dan media itu pada umumnya hanya relevan digunakan pada masa yang bersangkutan. Sehingga untuk memanfaakannya secara dominan dalam dakwah masa kini, jelas relevansinya dan efektifitas serta efesiensinya tidak sama. Untuk itulah perlu ditinjau kembali pada bagian-bagian tertentu sesuai dengan permasalahan atau duduk perkaranya.

\section{Hasil-hasil yang Dicapai}

Peta sejarah dakwah terus berkembang luas ke beberapa wilayah, secara bertahap bergerak dari satu wilayah ke wilayah 
berikutnya meskipun tempat yang dimasukinya berbeda-beda. Kesan yang menonjol sekali ialah bahwa citra atau corak agama Islam tak pernah pudar di segala tempat/keadaan yang pernah menjadi terminalnya.

Memang dakwah Islamiyah dalam masa setelah Khulafaur Rasyidin ini merupakan era baru dalam lembaran sejarah Islam, baik segi-segi yang positifnya atau segi-segi yang dikatakan negatif. Capaian Hasil yang telah diberikan dinasti Bani Umaiyah secara umum meliputi pembinaan dan pengembangan ilmu pengetahuan yang dibarengi dengan teknologinya, kemudian diikuti dengan pengembangan dan pembinaan sayap kekuasaan atau membangun daerah yang takluk dengan rezim Islam pada waktu itu, baik di bawah kepemimpinan Rasulullah SAW. dulu maupun di masa Khulafaur Rasyidin dan lebih-lebih pada periode Bani Umaiyah sendiri.

Menurut Haidar Bammate, para Khalifah Bani Umaiyah ratarata dikenal sebagai orang yang supel dalam pergaulan mereka dengan para ilmuwan meskipun mereka berasal dari agama yang berbeda. Meskipun para penguasa saat itu masih bertahan dengan agama mereka seperti Yahudi dan Kristen, mereka tetap dihormati, dimuliakan dan malah tidak jarang dianggap sebagai guru. Paling tidak profesionalisme mereka di bidang ilmu pengetahuan dan teknologi dimanfaatkan untuk kepentingan pembangunan khilafah. ${ }^{41}$ Kemajuan ilmu pengetahuan dan teknologi yang dirintis daulat Bani Umaiyah ini, tidak saja dinyatakan oleh penulis-penulis Islam sendiri secara sepihak, tapi juga diakui oleh penulis di luar Islam, umpamanya Roger Garandy dari Perancis dalam bukunya "Promesses De L' Islam", mengakui bahwa armada angkatan laut Islam telah menjelajahi dunia

\footnotetext{
${ }^{41}$ Haidar Bammate, Sumbangan Islam Kepada Peradaban, terj. O. Hashem, Surabaya, 1963, hal. 12.
} 
sejak zaman khalifah Muawiyah. ${ }^{42}$ ini menjadi bukti bahwa saat khalifah-khalifah memegang kendali daulah Islamiyah, mereka tidak mau ketinggalan dengan pengembangan ilmu sain dengan teknologi.

Kekhalifahan Bani Umaiyah secara khas mencirikan dari "zaman emas Islam" (The Islamic Golden Age), dimana tidak ada suatu kerajaan Arab lainnya yang dapat menandingi ini, baik tentang luasnya maupun mengenai cepatnya bagaikan kilat. Demikian hasilhasil yang diraih pemerintahan Bani Umaiyah yang memerintah hampir satu abad lamanya itu, yang disoroti melalui kacamata dakwah Islamiyah. Selian itu hasil-hasil ilmu pengetahuan yang dicapai juga diakui oleh penulis non Muslim. Secara mendasar hasil yang dicapai itu meliputi dua aspek, yaitu perluasan wilayah dan pengembangan ilmu pengetahuan, dan pemikiran dibidang ekonomi, sehingga dari sanalah terbukalah ilmu pengetahuan dunia Barat dan Timur serta budaya, yang hingga sampai kini masih terasa pengaruhnya. Secara spesifik dampak positif yang masih berkembang hingga masa-masa yang akan datang dari hasil yang dicapai adalah masih berlangsungnya kegiatan dakwah Islam hingga ke segala pelosok belahan dunia.

\section{Simpulan}

Dinasti Umayyah sebagai dinasti awal pertama dalam dunia islam telah membawa kemajuan yang sangat pesat dalam penyebaran islam keseluruh dunia, walaupun tidak dapat dipungkiri sejarah politik memperoleh persepsi negative dalam perubahan demokratis ke monarchy namun hal tersebut bukanlah menjadi suatu kelemahan bahwa dinasti Umayyah dalam sejarah Panjang banyak memiliki kontribusi yang sangat menggembirakan sehingga islam dapat

\footnotetext{
${ }^{42}$ Roger Garandy, Promesses De'l Islam, terj. Prof. Dr. H. M. Rasyidi, Jakarta, 1982, hal. 124.
} 
tersebar dan dikenal ke berbagai penjuru dunia, demikian dapat disimpulkan bahwa sejarah dakwah pada masa bani umayyah dimulai dengan perluasan wilayah dakwah seiring ekspansi teritorial yang dilakukan oleh bani umayyah di beberapa wilayah, serta pengembangan ilmu pengetahuan sebagaimana menjadikan bahasa Arab menjadi bahasa administratif, dan pemikiran dakwah di bidang ekonomi seperti pengeloaan baitul Maal, mengganti mata uang dan pengeloaan pajak.

\section{Daftar Pustaka}

Amin, Samsul Munir. Sejarah Peradaban Islam. Jakarta: Amzah, 2010. Bammate, Haidar. Sumbangan Islam Kepada Peradaban. Translated by O Hashem. Surabaya: JAPI, 1963.

Garaudi, Roger. Promesses De'l Islam. Jakarta: Bulan Bintang, 1982. Hasjmy, A. Sejarah Kebudayaan Islam. Jakarta: Bulan Bintang, 1995. Hassan, Hassan Ibrahim. Sejarah Dan Kebudayaan Islam. Yogyakarta: Kota Kembang, 1989.

Nazaruddin. Publisistik Dan Da'wah: (Persamaan Dan Perbedaannya): Erlangga, 1974.

Nur Chamid. Jejak Langkah Sejarah Pemikiran Ekonomi Islam. Yogyakarta: PUSTAKA PELAJAR, 2010.

Quthb, Sayyid. Al-Adalah Al-Ijtimaiyyah Fil Islam. Bandung: Pustaka, 1994.

Siti Maryam, dkk. (ed.). Sejarah Peradaban Islam: Dari Masa Klasik Hingga Modern. Yogyakarta: LESFI, 2004.

Wahyu Ilaihi \& Harjani Hefni. Pengantar Sejarah Dakwah. Jakarta: Kencana Prenada Media Group, 2007.

Ya'qub. Publisistik Islam: Teknik Da'wah Dan Leadership: Bandung: Diponegoro, 1981.

https://en.wikipedia.org/wiki/List_of_Caliphs 